DOI: https://doi.org/10.32839/2304-5809/2021-11-99-6

УДК 343.915:364.048.6

Светлічна O.B. ${ }^{1}$

психолог

Светлічний I.B. ${ }^{2}$

Інститут держави і права імені В.М. Корецького

Національної академії наук України

\title{
АКТУАЛЬНІ ПИТАННЯ ПРОТИДІЇ ЗЛОЧИННОСТІ НЕПОВНОЛІТНІХ ЗАСОБАМИ ВІДНОВНОГО ПРАВОСУДДЯ
}

\begin{abstract}
Анотація. Досліджено деякі актуальні питання протидії злочинності неповнолітніх засобами відновного правосуддя, їх ресоціалізації, в тому числі проблемні питання звільнення від кримінальної відповідальності неповнолітніх, які після вчинення окремих тяжких злочинів примирилися 3 потерплими та відшкодували завдану шкоду. В результаті досліджень встановлено, що на теперішній час деякі проблемні питання протидії злочинності неповнолітніх засобами відновного правосуддя не мають шляхів вирішення національними правовими засобами. Недосконала законодавча техніка, неналежна якість правових норм призводить до типових помилок у судовій практиці. Потребують подальших досліджень й шляхи вирішення існуючих проблемних питань протидії злочинності неповнолітніх, зокрема, засобами відновного правосуддя. Доведено, що протидія злочинності неповнолітніх засобами відновного правосуддя сприятиме максимальному виведенню неповнолітніх правопорушників з кримінального процесу та запобігання скоєнню ними повторних злочинів.
\end{abstract}

Ключові слова: кримінальне правопорушення, неповнолітні, молоді люди, кримінальне провадження, примирення, відновлення стосунків, відновне правосуддя, зелена кімната, допит, ресоціалізація, звільнення від кримінальної відповідальності.

Svietlichna Olena psychologist

Svietlichnyi Igor

V.M. Koretsky Institute of State and Law of the National Academy of Sciences of Ukraine

\section{TOPICAL ISSUES OF COUNTERING JUVENILE DELINQUENCY BY MEANS OF RESTORATIVE JUSTICE}

Summary. Some topical issues of countering juvenile delinquency by means of restorative justice are investigated, including the problem of exemption from criminal liability of minors who, after committing certain serious crimes, reconciled with the victim and compensated for the damage caused. As a result of research, it has been established that currently some issues of countering juvenile delinquency by means of restorative justice do not have ways to solve them by national legal means. Imperfect legislative technique, inadequate quality of legal norms leads to typical errors in judicial practice. Ways to solve the existing problems of countering juvenile delinquency by means of restorative justice also require further research. According to the author, it is necessary to apply for minors and such opportunities of legislation that the legislator provided for adults. These include exemption from criminal liability on the basis of articles 45-48 of the Criminal Code of Ukraine, exemption from criminal punishment on the basis of articles 74, 83-87, 104 of the Criminal Code of Ukraine and others, if such exemption is the best option for a particular minor. Administrative liability in Ukraine begins at the age of 16 , a minor is not responsible for the damage caused by him. However, responsibility for criminal offenses, crimes, according to part two of Article 22 of the Criminal Code of Ukraine, occurs for a child in the most common types of crimes from the age of 14: theft, causing bodily harm, possession of vehicles, crimes against sexual freedom and inviolability, etc. Thus, criminal liability from the age of 14 applies to a child for almost all criminal offenses and crimes that children at this age can commit. From the age of 11 to 14 (in appropriate cases up to 16) years, that is, until the age of criminal responsibility, compulsory educational measures can be applied to a child who has committed a crime, but is not the subject of a crime due to age. The most severe compulsory measure of an educational nature is the placement of a child in a special educational institution (closed-type institution), which was used in 2014 in almost 12 percent of court decisions. The criminal process is the most traumatic for the psyche of children, says psychologist Liudmyla Gridkovets. The "green room"method of interrogating a child is effective. This method is designed for the purpose of non-traumatic interrogation of the child and provides an opportunity to collect the necessary evidence in the case. The application of the principles of restorative justice to counteract juvenile delinquency leads to a faster restoration of relations between participants, reduces the psychological traumatization of young people due to the positive psychological atmosphere that develops in the processes of reconciliation and restoration of relations, and will contribute to the maximum removal of juvenile offenders from the criminal process and prevent them from committing repeated crimes in the future, as psychologist Olena Svietlichna notes. Thus, countering juvenile delinquency by means of restorative justice will contribute to the maximum removal of juvenile offenders from the criminal process and prevent them from committing repeated crimes.

Keywords: criminal offense, minors, young people, criminal proceedings, restorative justice, exemption from criminal liability. 
$\Pi$ остановка проблеми. На теперішній час деякі проблемні питання протидії злочинності неповнолітніх засобами відновного правосуддя не мають шляхів вирішення національними правовими засобами. Зазначене стосуеться, зокрема, звільнення від кримінальної відповідальності неповнолітніх, які після вчинення окремих тяжких злочинів примирилися 3 потерплим та відшкодували завдану шкоду.

Існуе думка, що покарання - це обов'язкова відповідь на несправедливість. Проте, відповідь на запитання «чому неповнолітній злодій завжди має сидіти у в'язниці?», - не очевидна. На практиці покарання неповнолітніх не досягає мети виправлення правопорушника. Кращий спосіб вирішення питань, які турбують і потерпілого, і неповнолітнього правопорушника, - відновне правосуддя.

Загальновідомо, що недосконала законодавча техніка, неналежна якість правових норм призводить до типових помилок у судовій практиці. Саме тому шляхи вирішення існуючих проблемних питань протидії злочинності неповнолітніх, в тому числі, засобами відновного правосуддя потребують подальших досліджень.

Аналіз останніх досліджень і публікацій. В українській юридичній літературі зазначена проблема є вкрай малодослідженою. Відповідні пропозиції містяться у проекті нового Кримінального кодексу, зокрема, у дослідженнях О.П. Гороха, робочої групи з питань розвитку кримінального права, що діє у складі Комісії 3 питань правової редорми при Президентові України, яка здійснює розробку нового Кримінального кодексу України та Кодексу України про проступки. (З текстом документа можна ознайомитися на сайті нового Кримінального кодексу України за посиланням: https://newcriminalcode.org.ua/). Про необхідність застосування кращого зарубіжного досвіду з питань протидії злочинності неповнолітніх засобами відновного правосуддя зазначали О. П. Горох, О. М. Костенко, Р. Г. Коваль, I. В. Свєтлічний, X. I. Романюк, Л. Л. Гретченко та інші [1].

Крім цього, в законодавство більшості розвинутих країн світу імплементований значно вищий, ніж в Україні, вік, до якого молода людина має право на особливе піклування та підтримку, в тому числі звільнення від кримінальної відповідальності. У країнах англосаксонської системи права суд може звільнити від кримінальної відповідальності неповнолітніх та молодих людей, якщо винний діяв без достатнього розуміння. Icнуе думка (Г. Андрусяк), що в разі встановлення вікової межі кримінальної відповідальності на дуже низькому рівні поняття відповідальності «стає безглуздим». В Україні вказані проблеми досліджуються, в тому числі А. С. Нерсесяном, І. В. Светлічним, О. П. Горох, О. М. Костенко, Р. Г. Коваль, Л. Л. Гретченко.

Виділення невирішених раніше частин загальної проблеми. Конвенція Організації Об'єднаних Нащій про права дитини (ратифікована Постановою Верховної Ради України № 789-XII від 27.02.1991 року) визначає, що діти мають право на особливе піклування і допомогу, захист і сприяння, щоб вони могли повністю покласти на себе зобов'язання в рамках суспільства [2].
Декларація прав дитини, прийнята резолюцією 1386 (XIV) Генеральної Асамблеї ООН від 20.11.1959 року, також обумовлюе, що дитина, внаслідок їі фрізичної і розумової незрілості, потребує спеціальної охорони і піклування, включаючи належний правовий захист як до, так і після народження, а також принципом 8 імперативно закріплюе право дитини за будь-яких обставин бути серед тих, які першими одержують захист і допомогу [3].

Вказана конвенція особливу увагу приділяє зобов'язанням держав - учасниць, щоб кожна позбавлена волі дитина мала право на негайний доступ до правової та іншої відповідної допомоги (ст. 37) та забезпечення ними в складі мінімальних гарантій кожній дитині, що, як вважається, порушила кримінальне законодавство чи звинувачуеться в його порушенні, одержання правової й іншої необхідної допомоги при підготовці та здійсненні свого захисту (ст. 40).

За визначенням профресора О.М. Костенка, "Держава має сприяти вихованню нового покоління громадян, створюючи у суспільстві умови для узгодження їхньої волі і свідомості із законами сощіальної природи" [4, с. 41].

У 2019 році розпочалася "Програма відновлення для неповнолітніх, підозрюваних у вчиненні злочину", мета якої - забезпечення відшкодування заподіяної шкоди, максимальне виведення неповнолітніх правопорушників 3 кримінального процесу та запобігання скоєнню ними повторних злочинів. Правова основа цієї програми - спільний наказ Міністерства юстиції України та Генеральної прокуратури № 172/5/10 від 21.01.2019 року. Крім цього, в Україні діє проект "Впровадження відновного правосуддя в Україні”, мета якого - застосування відновного правосуддя для попередження злочинності. Цей проект реалізується Верховним Судом та ГО "Інститут миру і порозуміння".

На думку авторів варто застосовувати для неповнолітніх й такі можливості законодавства, які законодавець передбачив для повнолітніх осіб. До них ми відносимо звільнення від кримінальної відповідальності на підставах статей 45-48 Кримінального кодексу України (КК України), звільнення від кримінального покарання на підставах статей 74, 83-87, 104 КК України та інших, якщо таке звільнення є найкращим варіантом для конкретного неповнолітнього.

Мета статті. Головною метою ціеї роботи $є$ дослідження деяких питань протидії злочинності неповнолітніх засобами відновного правосуддя, в тому числі звільнення від кримінальної відповідальності неповнолітніх, які після вчинення окремих тяжких злочинів примирилися 3 потерплим та відшкодували завдану шкоду. На думку авторів, засоби відновного правосуддя сприятимуть максимальному виведенню неповнолітніх правопорушників 3 кримінального процесу, їх ресоціалізації та запобіганню скоєнню ними повторних злочинів.

Виклад основного матеріалу. Адміністративна відповідальність в Україні настає з 16 років, малолітня особа не несе відповідальності за завдану нею шкоду. Проте відповідальність за кримінальні правопорушення, злочини, згідно із частиною другою статті 22 КК України, настає 
для дитини за найбільш розповсюдженими складами злочинів вже 314 років Це крадіжки, нанесення тілесних ушкоджень, заволодіння транспортними засобами, злочини проти статевої свободи та недоторканності тощо. Таким чином, кримінальна відповідальність 314 років застосовуеться до дитини майже за всі кримінальні правопорушення та злочини, які можуть вчинити діти у такому віці.

311 років до 14 (у відповідних випадках згідно частини першої статі 22 КК України до 16) років, тобто до настання віку кримінальної відповідальності, до дитини, яка вчинила злочин, але не є суб'єктом злочину внаслідок віку, можуть бути застосовані примусові заходи виховного характеру (ПЗВХ). Найжорстокішим примусовим заходом виховного характеру є поміщення дитини до спеціальної навчально-виховної установи (установи закритого типу), який застосовувався на 2014 рік майже у 12 відсотках судових рішень щодо застосування ПЗВХ [5].

Кримінальний процес є найбільш травматичним для психіки дітей, як зазначає у своїх дослідженнях Л. М. Гридковець. Застосування принципів відновного правосуддя щодо неповнолітніх призводить до більш швидкого відновлення стосунків між учасниками, зменшуе психологічну травматизацію молодих людей завдяки позитивній психологічній атмосфері, яка складається при процесах примирення та відновлення стосунків, а в подальшому сприятиме максимальному виведенню неповнолітніх правопорушників 3 кримінального процесу та запобігання скоєнню ними повторних злочинів, як зазначає у своїх дослідженнях психолог О. В. Светлічна.

Методика "зелена кімната" вважається едективною для допиту дитини. Зазначена методика розроблена з метою уникнення травмуючого впливу допиту та забезпечує можливість зібрати необхідні докази у справі. Суть їі полягає в дружній атмоссрері, сприятливій для дітей.

Зазначимо, що у випадку, якщо вік дитини не встановлено, проте $є$ підстави вважати що дитина $є$ малолітньою або неповнолітньою, до встановлення віку такої дитини ії допит слід проводити за правилами, передбаченими для допиту малолітньої або неповнолітньої особи, застосовуючи методику “зелена кімната". Крім цього, коли існує необхідність неодноразово отримати індормацію від дитини (допит слідчим, опитування, при проведенні різного виду експертиз, психологічних досліджень), допит слід проводити, застосовуючи методику “зелена кімната" та бажано лише один раз для зменшення повторної психологічної травматизації дитини. Чинний КПК України у статті 224 передбачає можливість проводити допит не тільки за місцем проведення досудового розслідування, а також в іншому місці за погодженням із особою, яку мають намір допитати. Тому місце для допиту має бути обрано так, щоб забезпечити зменшення психологічної травматизації дитини. Допит може відбуватися за місцем проживання чи місцем навчання дитини в дружній для дитини атмосфрері, що буде сприяти забезпеченню найкращих інтересів дитини при допиті.

До прикладу застосування дистанційного судового провадження за участі дитини можна розглянути судову справу № 317/2782/20. Суд задовольнив клопотання про допит неповнолітнього поза залою судового засідання в іншому приміщенні 3 використанням відеоконфреренції (дистанщійне судове провадження), крім цього, суд вважав необхідним залучити психолога (https://vkursi.pro/vsudi/decision/95956447). Своє piшення суд обгрунтував необхідністю запобігти або мінімізувати психологічне травмування малолітніх потерпілих, яке може бути викликане їхнім особистим візуальним контактом з обвинуваченим.

Крім того, існує можливість уникнення повторного допиту дитини під час судового розгляду кримінального провадження. Така можливість передбачена статтею 225 КПК України, згідно якої у виняткових випадках, пов'язаних із необхідністю отримання показань свідка чи потерпілого під час досудового розслідування, якщо через існування небезпеки для життя і здоров'я свідка чи потерпілого, їх тяжкої хвороби, наявності інших обставин, що можуть унеможливити їхній допит в суді або вплинути на повноту чи достовірність показань, сторона кримінального провадження, представник юридичної особи, щодо якої здійснюеться провадження, мають право звернутися до слідчого судді із клопотанням провести допит такого свідка чи потерпілого в судовому засіданні, у тому числі одночасний допит двох чи більше вже допитаних осіб. У цьому випадку допит свідка чи потерпілого здійснюеться в судовому засіданні в місці розташування суду або перебування хворого свідка, потерпілого в присутності сторін кримінального провадження 3 дотриманням правил проведення допиту під час судового розгляду.

Проблемні питання участі законних представників дитини полягають у наступному. Адвокат $\epsilon$ єдиною особою, без якої неможливий на практищі хід кримінального процесу за участю дитини в статусі підозрюваної (обвинуваченої) особи. Такий висновок можна зробити на підставі системного аналізу статей 488, 491 КПК України. У деяких випадках батьки, близькі родичі чи законні представники дитини не з'являються для проведення процесуальних дій. Тому можемо зробити висновок, що згідно з практикою, яка склалася в Україні при захисті неповнолітніх, неявка будького, крім адвоката та прокурора (в суд), не перешкоджає кримінальному процесу щодо дитини, але завдає шкоди інтересам дитини.

Крім цього, проблематичним стає застосування відновного правосуддя у випадку деструктивної позиції батьків або законних представників, а саме заперечення основних фрактів справи, незгода 3 фрактичними обставинам. Вказане буде перешкодою для застосування звільнення від кримінальної відповідальності, звільнення від кримінального покарання, навіть при застосуванні відновного правосуддя.

Розглянемо випадок із практики автора, розміщений на електронному ресурсі системи безоплатної правової допомоги Міністерства юстиції України. У 13-річного хлопця, який скоїв правопорушення у малолітньому віщі, не було нікого, крім адвоката. Слідчі органи просили суд помістити дитину до приймальника-розподільника, проте адвокат зміг цьому запобігти, що скоріше $є$ виключенням та щасливим збігом обставин для 
дитини, враховуючи, що близьких родичів у дитини не було [6].

Висновки і пропозиції. Статтею 2 КПК України встановлено, що завданням кримінального провадження є не лише захист особи, суспільства та держави від кримінальних правопорушень, а й охорона прав, свобод та законних інтересів учасників кримінального провадження, гарантування того, щоб до кожного учасника кримінального провадження була застосована належна правова процедура [7, с. 422]. Під час кримінального провадження, також щодо неповнолітніх, мають бути гарантовані права підозрюваного та обвинуваченого, про що неодноразово зазначав Свропейський суд з прав людини, до прикладу, у рішенні від 16.12.1999 у справі “Т. проти Великої Британіі” та низці відповідних рішень [8].
Таким чином, протидія злочинності неповнолітніх засобами відновного правосуддя сприятиме максимальному виведенню неповнолітніх правопорушників 3 кримінального процесу, їx ресоціалізації та запобіганню скоенню ними повторних злочинів.

Пропозищії авторів включають, серед іншого, імплементацію до чинного законодавства поняття "молоді люди" (віком до 21 року) та впровадження у законодавство можливостей для звільнення молодих людей від кримінальної відповідальності або покарання в разі вчинення ними окремих тяжких злочинів, в тому числі звільнення від кримінальної відповідальності неповнолітніх, які обвинувачуються у тяжких злочинах, але примирилися та відшкодували завдану шкоду.

\section{Список літератури:}

1. Светлічний I. В. Деякі актуальні питання кримінально-правової охорони прав неповнолітніх у кримінальному процесі, імплементації принципів відновного правосуддя щодо дітей та молодих людей. Держава $i$ право. Юридичні і політичні науки. 2020. Вип. 88. С. 212-224. URL: http://nbuv.gov.ua/UJRN/dip_2020_88_22

2. Конвенція про права дитини (ратифрікована Постановою ВР України № 789-XII від 27.02.1991. URL: https://zakon.rada.gov.ua/laws/show/995_021

3. Декларація прав дитини (прийнята резолюцією 1386 (XIV) Генеральної Асамблеї ООН від 20.11.1959). URL: https://zakon.rada.gov.ua/laws/show/995_384

4. Костенко О. М. Соціальний натуралізм. Про соціальну природу та її закони. Івано-Франківськ : Петраш K. T., 2019. 72 c.

5. Комітет НААУ захисту прав людини провів круглий стіл на тему: “Досвід застосування відновного правосуддя у країнах Європи: погляд адвоката". URL: https://unba.org.ua/news/print/5707-komitet-naau-zahistu-pravlyudini-proviv-kruglij-stil-na-temu-dosvid-zastosuvannya-vidnovnogo-pravosuddya-u-krainah-evropi-poglyadadvokata.html

6. Хроніки успішних та/або резонансних справ за участі адвокатів системи БВПД. URL: https://www.legalaid.gov.ua/ publikatsiyi/hroniky-uspishnyh-ta-abo-rezonansnyh-sprav-za-uchasti-advokativ-systemy-bvpd/

7. Светлічний I. В., Зейкан Я. П. Практика проваджень в антикорупційних справах : наук.-практ. посіб. Київ : Юрінком Інтер, 2020. 452 с.

8. Лист ВССУ від 16.01.2017 № 223-66/0/4-17 про практику здійснення судами кримінального провадження щодо неповнолітніх. URL: https://zib.com.ua/ua/print/127476-list_vssu_vid_16012017_223-6604-17_pro_ praktiku_zdiysnennya_.html

\section{References:}

1. Svietlichnyi I. V. (2020) Deyaki aktualni pytannia kriminalno-pravovoi okhorona prav nepovnolitnih u kryminal'nomu protsesi, implementatsii pryntsypiv vidnovnoho pravosuddia schodo ditej ta molodykh liudej. Derzhava i pravo. Yurydychni i politychni nauky, no. 88, pp. 212-224. Available at: http://nbuv.gov.ua/UJRN/ dip_2020_88_22

2. Konvencija pro prava dytyny (ratyfikovana Postanovoiu VR Ukrainy № 789-XII vid 27.02.1991. Available at: https://zakon.rada.gov.ua/laws/show/995_021

3. Deklaratsiia prav dytyny (pryjniata rezoliutsiieiu 1386 (XIV) Heneral'noi Asamblei OON vid 20.11.1959). Available at: https://zakon.rada.gov.ua/laws/show/995_384

4. Kostenko O. M. (2019) Sotsial'nyj naturalizm. Pro sotsial'nu pryrodu ta ii zakony. Ivano-Frankivs'k: Petrash K. T., 72 p.

5. Komitet NAAU zahystu prav liudyny proviv kruglyj stil na temu: "Dosvid zastosuvannia vidnovnoho pravosuddia u krainakh Yevropy: pohliad advokata”. Available at: https://unba.org.ua/news/print/5707-komitet-naau-zahistuprav-lyudini-proviv-kruglij-stil-na-temu-dosvid-zastosuvannya-vidnovnogo-pravosuddya-u-krainah-evropipoglyad-advokata.html

6. Khroniky uspishnykh ta/abo rezonansnykh sprav za uchasti advokativ systemy BVPD. Available at: https://www.legalaid.gov.ua/publikatsiyi/hroniky-uspishnyh-ta-abo-rezonansnyh-sprav-za-uchasti-advokativsystemy-bvpd/

7. Svietlichnyi I. V., Zeykan Ya. P. (2020) Praktyka provadzhen' v antykoruptsijnykh spravakh: nauk.-prakt. posib. Kyiv: Yurincom Inter, $452 \mathrm{p}$.

8. Lyst VSSU vid 16.01.2017 № 223-66/0/4-17 pro praktyku zdijsnennja sudamy kriminalnogo provadzhennya schodo nepovnolitnih. Available at: https://zib.com.ua/ua/print/127476-list_vssu_vid_16012017_223-6604-17_pro_ praktiku_zdiysnennya_.html 